\title{
Differential expression of hedgehog signaling components and Snail/E-cadherin in human brain tumors
}

\author{
CHIA-HUA CHOU ${ }^{1,6^{*}}$, ANN-SHUNG LIEU ${ }^{2,5^{*}}$, CHIA-HUNG WU ${ }^{*}$, LI-KWAN CHANG ${ }^{3}$, JOON-KHIM LOH $^{4}$, \\ RUN-CHIN LIN ${ }^{1}$, WEI-JAY CHEN ${ }^{1}$, HUEI-DE LIAO ${ }^{1}$, WEN-SHANE FU ${ }^{1}$, CHUNG-SHING CHANG ${ }^{5}$, \\ CHING-CHIH LIN ${ }^{1,5}$, CHING-MEI HSU ${ }^{6}$, $\mathrm{CHUNG}^{-C H I N G ~} \mathrm{CHIO}^{7}$, \\ SHEN-LONG HOWNG ${ }^{2,4}$ and YI-REN HONG ${ }^{1,2}$ \\ ${ }^{1}$ Department of Biochemistry, Faculty of Medicine, ${ }^{2}$ Graduate Institute of Medicine, College of Medicine, Kaohsiung \\ Medical University, Kaohsiung; ${ }^{3}$ Department of Biochemical Science and Technology, Institute of Microbiology \\ and Biochemistry, National Taiwan University, Taipei; Departments of ${ }^{4}$ Neurosurgery and ${ }^{5}$ Dermatology, \\ Kaohsiung Medical University Hospital; ${ }^{6}$ Department of Biological Sciences, National Sun Yat-Sen University, \\ Kaohsiung; ${ }^{7}$ Department of Neurosurgery, Chi Mei Medical Center, Tainan, Taiwan, R.O.C.
}

Received April 16, 2010; Accepted June 30, 2010

DOI: $10.3892 /$ or_00000976

\begin{abstract}
The hedgehog ( $\mathrm{Hh}$ ) transcription factor Gli induces transformation of epithelial cells via induction of Snail, a repressor of E-cadherin. Epithelial-mesenchymal transition is also a determinant of the progression of tumorigenesis, following down-regulation of E-cadherin. However, the role of Hh signaling components and Snail/E-cadherin in brain tumors is not yet fully understood. We analyzed the expression of Hh signaling components and Snail/E-cadherin in 69 brain tumors by reverse transcription-polymerase chain reaction (RT-PCR). The data showed that overexpression of Smo (35/69), Ptch (50/69), Gli1 (56/69), Gli2 (29/69) and $\mathrm{N}$-myc (39/69) might contribute to brain tumorigenesis. Our results also indicated that Snail and E-cadherin showed opposing expression in malignant tumors (high grade astrocytoma and metastasis). Snail and E-cadherin showed less correlation in benign brain tumors. We further investigated mutations of Gli2 and Snail by RT-PCR and direct sequencing. No mutation was observed on Gli2 but several sporadic mutations on Snail were found, including S96G, S111L, S111L/ S119Y and one nonsense mutation at codon 158 (Y158*). An in vitro E-cadherin promoter assay showed that $\mathrm{S} 96 \mathrm{G}$, S111L, S111L/S119Y Snail mutants were decreased by 15 ,
\end{abstract}

Correspondence to: Dr Yi-Ren Hong, Department of Biochemistry, Faculty of Medicine, College of Medicine, Kaohsiung Medical University, no. 100, Shih-Chuan 1st Road, Kaohsiung 80708; or Dr Shen-Long Howng, Neurosurgery, Kaohsiung Medical University Hospital, Taiwan, R.O.C.

E-mail:m835016@cc.kmu.edu.tw

E-mail: slhowng@cc.kmu.edu.tw

*Contributed equally

Key words: hedgehog pathway, Snail, E-cadherin, brain tumor, localization
25 and $50 \%$, respectively, whereas Y158* was increased by $40 \%$ compared to wild-type. Furthermore, our data showed that wild-type Snail and S96G, S111L, S111L/S119Y translocated to the nucleus, while the Y158* mutant failed to translocate to the nucleus. Taken together, our results demonstrate that Hh signaling components, the expression and mutations of Snail and the expression of E-cadherin may play an important role in human brain tumorigenesis.

\section{Introduction}

The development of brain tumors such as medulloblastomas, neuroblastomas, ganglioneuromas and meningiomas differs with age and tissue location. Astrocytomas and glioblastomas are more often found in people over 35 years old. Astrocytomas and neuroblastoma are differentiated from neuroepithelial cells and malignant cells tend to occur at different ages $(1,2)$.

In our previous studies, we examined the differential expression of Wnt genes, downstream effector ß-catenin, transcriptional factor Tcf-4, E-cadherin and cell-cell adhesion molecules; and screened for 3 -catenin and Tcf-4 mutations in human brain tumors (3-5). These previous data suggested that mutations in B-catenin, E-cadherin, Tcf-4 isoforms and Wnt signaling genes might be involved in brain tumorigenesis. Recent evidence implying a pathological role for the Wnt and Hh pathways has emerged from studies showing that high frequency of specific human cancers share several related components, for example GSK3ß. Misregulation of the components in the Hh signaling pathway may lead to cancer in different tissues, for example, basal cell carcinoma (BCC) of the skin and medulloblastoma $(6,7)$.

The hedgehog $(\mathrm{Hh})$ gene was originally identified in flies, where it is first required for patterning of the early embryo $(7,8)$. In mammals, the Hh family consists of three different members, Sonic hedgehog (Shh), Indian hedgehog (Ihh) and Desert hedgehog (Dhh) (9). Shh is the most broadly expressed member and is involved in the patterning and growth of a 
large variety of organs, including the brain, skin, lung, prostate, gastrointestinal tract and skeletal system (10). Hh proteins, by binding to the Patched (Ptc) receptor, release Ptc inhibition of Smoothened (Smo), a membrane protein related to $\mathrm{G}$ protein-coupled receptors, which then regulates a protein complex that includs $\mathrm{Cos} 2, \mathrm{Fu}$ and $\mathrm{Su}(\mathrm{Fu})$ in Drosophila (11), and then transduces a signal for activation and nuclear translocation of a family of transcriptional factors, Cubitus interruptus (Ci) in Drosophila and Glis (Gli1, Gli2 and Gli3) in vertebrate Gli genes. A highly conserved DNA binding domain of Gli proteins comprises 5 zinc finger domains of the $\mathrm{C} 2-\mathrm{H} 2$ class and all Gli proteins were shown to bind to the consensus sequence GACCACCCA (12). In addition, Gli proteins contain a C-terminal transactivation domain, but only Gli2 and Gli3 were shown to have an N-terminal repression domain. Evidence suggests that Gli1 and Gli2 represent the main activators of Hh-target genes, while Gli3 acts mainly as a repressor (13-15). In the absence of $\mathrm{Hh}$, Smo is localized mostly in vesicles (16) and $\mathrm{Ci}$ is phosphorylated by protein kinase A (PKA) at multiple sites, which prime additional phosphorylation at interspersed sites by the GSK3ß homologue shaggy and casein kinase-I $(17,18)$. Hyperphosphorylated Ci is targeted for proteasomal degradation to generate a repressor form. During pathway activation, Smo is enriched at the plasma membrane, and $\mathrm{Ci}$ phosphorylation is prevented, leading to stabilization and nuclear translocation of full-length Ci $(8,19)$. A similar phosphorylation pattern also found in Gli2/3 (15). In addition, N-myc acts downstream of Shh/Smo signaling during GNP proliferation. N-myc is required for medulloblastoma genesis even in the presence of constitutively active signaling from the Shh pathway (20). Constitutive activation of the $\mathrm{Hh} / \mathrm{Gli}$ signaling cascade has recently been implicated in the growth of a number of human malignancies ranging from semi-malignant tumors of the skin to highly aggressive cancers of the brain, lung, pancreas and prostate (3). The role of the Hh pathway in the pathogenesis of other brain tumors is still unknown.

Snail displays B-catenin-like canonical motifs that support its GSK3ß-dependent phosphorylation, $\beta$-TrCP-directed ubiquitination, and proteasomal degradation. Accordingly, Wnt signaling inhibits Snail phosphorylation and consequently increases Snail protein levels and activity while driving an in vivo epithelial-mesenchymal transition that is suppressed following Snail knockdown (21). E-cadherin is a type I integral membrane protein that localizes to adhere junctions and mediates $\mathrm{Ca}^{++}$-dependent cell-cell adhesion. The $\mathrm{C}$ terminus of E-cadherin is linked to $\alpha$-catenin and the actin cytoskeleton through association with B-catenin (22-25).

Epithelial-mesenchymal transition (EMT), a normal developmental process, is known to play a crucial role in tumor progression. Molecules involved in this process, such as the E-cadherin repressor Snail, facilitate migration and invasion of carcinoma cells. A growing number of studies address the expression of Snail in clinical samples (26). A hallmark for EMT is the loss of E-cadherin, a cell adhesion molecule and invasion suppressor. Down-regulation of Ecadherin can arise among other mechanisms through transcriptional repression. Several EMT regulators have been identified as E-cadherin repressors, including the zinc finger transcription factor Snail (27-29). Importantly, Snail not only induces invasion but also blocks the cell cycle and confers resistance to cell death (30-32). Endogenous Snail protein is present in invasive mouse and human carcinoma cell lines and tumors in which E-cadherin expression has been lost. Furthermore, the transcription factor Snail controls EMT by repressing E-cadherin expression $(28,30)$.

The cross-talk of hedgehog and Snail/E-cadherin regulated by GSK $3 ß$ remains unclear. Understanding the interplay of the hedgehog signaling pathway and Snail-E-cadherin axis in human brain tumors will help elucidate the protein-linkage map among Snail/E-cadherin, transcriptional factors (Gli, Snail) and kinase (GSK3ß). This will certainly provide a better understanding of brain tumorigenesis and contribute to brain cancer therapy. In the present study, we first examined the differential expression of Hh signaling pathway components (Shh, Ptch, Smo, Gli, N-myc) and Snail/E-cadherin in brain tumors. Next, we analyzed the mutation sites of the transcriptional factor Gli and Snail, which are regulated by GSK3ß.

\section{Materials and methods}

Tissue collection. Brain tumor samples were obtained from patients during surgery or biopsy from KMUH and patients following provision of informed consent according to the Ethics Committee guidelines of Kaohsiung Medical University, Taiwan. Tumors were classified according to Kleihues et al (2). Tissue samples were collected fresh at the time of surgery, snap frozen in liquid nitrogen and kept frozen at $-135^{\circ} \mathrm{C}$.

RNA extraction and cDNA synthesis. Total RNA was prepared from tissue samples and cultured cells using the acidic guanidine isothiosulfate phenol-chloroform technique followed by DNase I treatment (Promega Corp., Madison, WI). Total RNA $(2 \mu \mathrm{g})$ from each sample was reverse transcribed in a total volume of $22 \mu \mathrm{l}$ using Superscript II reverse transcriptase (Promega) according to the manufacturer's protocol. A negative control without reverse transcriptase was included in each cDNA synthesis.

PCR amplification of cDNA from tissue. Polymerase chain reaction (PCR) was performed in reaction buffer $[100 \mathrm{mM}$ Tris- $\mathrm{HCl}$ (pH 8.3), $500 \mathrm{mM} \mathrm{KCl}$ ] containing $1.5 \mathrm{mM} \mathrm{MgCl}_{2}$, $2 \mathrm{mM}$ dithiothreitol, $2 \mu \mathrm{l} \mathrm{cDNA}$ from the above reverse transcription (RT) reaction mix, 2.5 units Taq DNA polymerase (Boehringer Corp., Mannheim, Germany), $200 \mu \mathrm{M}$ of each dNTP (Promega), and $1 \mu \mathrm{M}$ of appropriate sense and antisense primers (Table I) in a reaction volume of $50 \mu 1$. Amplification was carried out in a 9600 Perkin-Elmer thermal cycler (Perkin-Elmer,) using the following protocol: $90 \mathrm{sec}$ denaturation at $95^{\circ} \mathrm{C}, 90 \mathrm{sec}$ annealing at appropriate temperature, and $90 \mathrm{sec}$ extension at $72^{\circ} \mathrm{C}$ for $25-35$ cycles. Products were run on a $1.5 \%(\mathrm{w} / \mathrm{v})$ agarose gel prepared with Tris/Boric acid/EDTA (TBE) buffer, stained with $15 \mu \mathrm{g} / \mathrm{ml}$ ethidium bromide and visualized under UV transillumination. Positive control $\beta$-actin primers were also tested on every sample to ensure that the samples were PCR-amplifiable. Negative controls without reverse transcriptase and without RNA were also included for each set of primers. For each set of primers, preliminary experiments were used to establish the appropriate 
Table I. Primer sequences for RT-PCR.

\begin{tabular}{|c|c|c|}
\hline Gene & Expected fragment length & Primer sequence \\
\hline \multirow[t]{2}{*}{ Shh } & 262 & F: 5'-CGGAGCGAGGAAGGGAAAG-3' \\
\hline & & R: 5'-TTGGGGATAAACTGCTTGTAGGC-3' \\
\hline \multirow[t]{2}{*}{ Smo } & 322 & F: 5'-TTACCTTCAGCTGCCACTTCTACG-3' \\
\hline & & R: 5'-GCCTTGGCAATCATCTTGCTCTTC-3' \\
\hline \multirow[t]{2}{*}{ Ptch } & 450 & F: 5'-CGCCTATGCCTGTCTAACCATGC-3' \\
\hline & & R: 5'-TAAATCCATGCTGAGAATTGCA-3' \\
\hline \multirow[t]{2}{*}{ Gli1 } & 413 & F: 5'-CAGAGAATGGAGCATCCTCC-3' \\
\hline & & R: 5'-TTCTGGCTCTTCCTGTAGCC-3' \\
\hline \multirow[t]{2}{*}{ Gli2 } & 310 & F: 5'-GCCATCAAGACCGAGAGCTC-3' \\
\hline & & R: 5'-CGGCCCATGAGCAGGAATCC-3' \\
\hline \multirow[t]{2}{*}{$\mathrm{N}$-myc } & 240 & F: 5'-GACCACAAGGCCCTCAGTAC-3' \\
\hline & & R: 5'-GTGGATGGGAAGGCATCGTT-3' \\
\hline \multirow[t]{2}{*}{ Snail } & 606 & F: 5'-TGCGCGAATCGGCGACCC-3' \\
\hline & & R: 5'-CCTAGAGAAGGCCTTCCCGCAG-3' \\
\hline \multirow[t]{2}{*}{ E-cadherin } & 535 & F: 5'-TGCTCTTGCTGTTTCTTCGG-3' \\
\hline & & R: 5'-ACCAGCAACGTGATTTCTGC-3' \\
\hline \multirow[t]{2}{*}{ ß-actin } & 309 & F: 5'-AGCGGGAAATCGTGCGTG-3' \\
\hline & & R: 5'-CAGGGTACAGGTGGTGC-3' \\
\hline
\end{tabular}

$\mathrm{F}$, forward primer; $\mathrm{R}$, reverse primer.

cycle number to ensure that each PCR reaction was within the linear phase of amplification. Normal brain tissue cDNA was purchased from Clontech (Human MTC Panel I) for comparison.

DNA sequencing. The brain tumor cDNA was screened for Snail and Gli2 mutants by PCR-direct sequencing. The nucleotide sequencing was performed by the dideoxy method (Sequenase, USB) or ABI PRISM 310 Genetic Analyzer (Perkin-Elmer).

Site-directed mutagenesis. All the mutations used in this study, the Snail S96G, S111L, S111L/S119Y and nonsense mutation at codon 158 (Y158*) mutant, were introduced by the PCRbased QuickChange method (Stratagene). Briefly, the mismatched oligonucleotides were used to construct mutants. Site-directed mutagenesis was basically performed from wildtype Snail on plasmid pBabe. Mutations were verified by DNA sequencing after the purification of plasmid DNA from single colonies.

Promoter luciferase assay. All mutants were sequenced to confirm that only the intended point mutations were introduced. The 293 cells were transfected with $2.0 \mu \mathrm{g}$ of pBabe, wild-type, S96G, S111L, S111L/S119Y and nonsense mutation at codon 158 (Y158*) Snail mutants, together with $8 \mu \mathrm{g}$ of pGL2Basic-EcadK1 luciferase reporter (Addgene). A total of $1 \mu \mathrm{g}$ of pSEAP-control (Clontech) was co-transfected to normalise transfection efficiency. A human embryo kidney 293 cell line was maintained in DMEM supplemented with
$10 \%$ FBS. DNA transfections were performed using lipofectamine 2000. Luciferase analysis was performed with Lucite-lite (Tropix) according to the manufacturer's directions. Measurements were carried out with a Topcounter (Packard). Luciferase readout was always obtained from triplicate transfections and averaged by using pSEAP-control (Clontech) as internal control. Data are presented as the mean \pm SD. pvalues were determined using a Student's t-test, ${ }^{*} \mathrm{p}<0.01$.

EGFP-Snail expression plasmid construction. To construct the pEGFP-Snail plasmids from the pBabe-Snail mutants, DNA fragments encoding Snail were amplified by PCR using Taq polymerase (Takara). The PCR fragments were then inserted into the EcoRI and BamHI sites of the pEGFP-C2 (Clontech) vector. pEGFP-Snail plasmids were transfected into HEK 293 cells using lipofectamine 2000. Transfected cells were stained with 4,6-diamidino-2 phenylindole (DAPI). Finally, cells were examined using an Olympus LSM Fluoview 5000 confocal laser-scanning microscope (Olympus).

\section{Results}

Distribution of hedgehog pathway genes in brain tumors. We used a Reverse-transcriptase-PCR (RT-PCR) approach to examine the expression of the hedgehog signaling components in 69 human brain tumors, 11 low grade astrocytomas, 23 high grade astrocytomas, 29 meningiomas and 6 brain metastasis, using the gene-specific primers listed in Table I. A representative experiment demonstrating amplification of Shh, Smo, Ptch, Gli1, Gli2 and N-myc, one of Hh signaling 




Figure 1. RT-PCR analysis of Shh, Smo, Ptch, Gli1, Gli2 and N-myc in various brain tumors. Data represent a minimum of three independent experiments. B-actin was used as internal control.

Table II. Expression of hedgehog pathway genes in brain tumors.

\begin{tabular}{|c|c|c|c|c|c|c|c|}
\hline \multirow[b]{2}{*}{ Type } & \multirow{2}{*}{$\begin{array}{l}\text { No. of } \\
\text { cases }\end{array}$} & \multicolumn{6}{|c|}{ No. of expression (\%) } \\
\hline & & $\operatorname{Shh}(\%)$ & Smo (\%) & $\operatorname{Ptch}(\%)$ & Gli1 (\%) & Gli2 (\%) & $\mathrm{N}$-myc (\%) \\
\hline Normala $^{\mathrm{a}}$ & & + & - & + & - & + & + \\
\hline $\begin{array}{l}\text { Astrocytoma } \\
\text { (low grade) }\end{array}$ & 11 & 3/11 (27) & 6/11(55) & 8/11 (73) & $5 / 11$ & 4/11 (36) & $3 / 11(27)$ \\
\hline $\begin{array}{l}\text { Astrocytoma } \\
\text { (high grade) }\end{array}$ & 23 & 4/23 (17) & $13 / 23(57)$ & $15 / 23(65)$ & $22 / 23$ & $7 / 23(30)$ & $13 / 23(57)$ \\
\hline Meningioma & 29 & $14 / 29(48)$ & $14 / 29(48)$ & $22 / 29(76)$ & $23 / 29$ & $17 / 29(59)$ & $21 / 29(72)$ \\
\hline Metastasis & 6 & 1/6 (16) & 2/6(33) & $5 / 6(83)$ & $6 / 6(100)$ & 1/6 (16) & 2/6 (33) \\
\hline Total & 69 & $22 / 69(32)$ & $35 / 69(51)$ & $50 / 69(72)$ & $56 / 69$ & $29 / 69(42)$ & $39 / 69(57)$ \\
\hline
\end{tabular}

aNormal brain tissue cDNA was purchased from Clontech. + , indicates expression; -, not detectable.

pathway target genes, from various cancerous tissue and normal brain tissue cDNA is shown in Fig. 1. The normal brain tissue cDNA purchased from Clontech could only amplify and detect Shh, Ptch, Gli2 and N-myc. In addition, the expression of Shh (22/69), Smo (35/69), Ptch (50/69), Gli1 (56/69), Gli2 (29/69) and N-myc (39/69) were found in brain tumor specimens (Table II). These data showed that the overexpression of Ptch and Gli1 might contribute to brain tumorigenesis and the Hh signaling pathway in brain tumor was ligand (Shh) independent. Our findings also indicated that Gli1 was expressed more than Gli2 and appeared to be more important than Gli2 in brain tumors, but not in low grade astrocytoma (Fig. 1 and Table II).

Distribution of Snail and E-cadherin genes in brain tumors. According to the hedgehog pathway transcriptional factor, Gli1 induces transformation of epithelial cells via induction of Snail, a repressor of $\mathrm{CDH}$ (E-cadherin); therefore, we used an RT-PCR approach to examine the expression of Snail and E-cadherin in human brain tumors. A representative experiment demonstrating amplification of Snail and E-cadherin from various cancerous tissues and normal brain tissue cDNA is shown in Fig. 2. Our data showed that the expression of Gli1 was $45 \%(5 / 11), 96 \%(22 / 23), 79 \%(23 / 29), 100 \%(6 / 6)$ in astrocytoma (low grade), astrocytoma (high grade), meningioma and metastatic tumors, respectively (Table II). The expression of Snail was 45\% (5/11), 74\% (17/23), 86\% $(25 / 29)$ and $100 \%(6 / 6)$ in astrocytoma (low grade), astrocytoma (high grade), meningioma and metastatic tumors, respectively. The expression of E-cadherin was $75 \%(3 / 11)$, $39 \%(9 / 23), 96 \%(28 / 29)$ and 50\% (3/6) in astrocytoma (low grade), astrocytoma (high grade), meningioma and metastatic tumors, respectively (Table III). The expression data showed an apparent negative correlation between Snail and E-cadherin in high grade astrocytoma and metastasis and seemed uncorrelated in meningioma and low grade astrocytoma. 




Figure 2. RT-PCR analysis of Snail and E-cadherin in brain tumors. Data represent a minimum of three independent experiments. B-actin was used as internal control.

Table III. Expression of Snail and E-cadherin genes in brain tumors.

\begin{tabular}{lccr}
\hline & & \multicolumn{2}{c}{ No. of expression (\%) } \\
\cline { 3 - 4 } Type & $\begin{array}{c}\text { No. of } \\
\text { cases }\end{array}$ & Snail (\%) & E-cadherin (\%) \\
\hline Normal $^{\mathrm{a}}$ & & - & + \\
$\begin{array}{l}\text { Astrocytoma } \\
\text { (low grade) }\end{array}$ & 11 & $5 / 11(45)$ & $8 / 11(75)$ \\
$\begin{array}{l}\text { Astrocytoma } \\
\text { (high grade) }\end{array}$ & 23 & $17 / 23 \quad(74)$ & $9 / 23(39)$ \\
$\begin{array}{l}\text { Meningioma } \\
\text { Metastasis }\end{array}$ & 29 & $25 / 29(86)$ & $28 / 29(96)$ \\
\hline
\end{tabular}

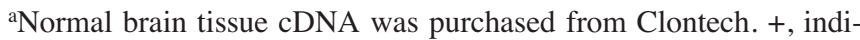
cates expression; -, not detectable.

Sequence analysis of Gli2 and Snail in brain tumors. The GSK3ß phosphorylation sites are important in Gli and Snail stability and function, in light of the existence of multiple phosphorylation sites within Snail and Gli2, with the consensus sequence S/TXXXS/T which is recognized by GSK3ß (33). We further investigated mutations of Gli2 and Snail by RT-PCR and direct sequencing in 69 brain tumors. No mutation was observed on Gli2 (data not shown), whereas several mutations were found in Snail including S96G, S111L, S111L/S119Y (double mutation) and one nonsense mutation at codon 158 (Y158*) (Table IV). These results indicated that Snail gene mutations were a sporadic and rare event in brain tumors.

Effect of Snail mutants on the promoter reporter assay. To examine whether these mutants changed transcriptional capability, we performed an in vitro E-cadherin promoter assay. These data showed that S96G, S111L and S111L/ S119Y Snail mutants decreased 15, 25 and 50\%, respectively, whereas the transcriptional capability of premature truncated mutant Y158* increased $40 \%$ compared to wild-type Snail (Fig. 3). The data appeared to show that the transcription-
Table IV. Summary of the mutations of Snail in brain tumors.

\begin{tabular}{|c|c|c|}
\hline Tumors & Case no. and mutation site & Frequencies \\
\hline Meningioma & $\begin{array}{l}\text { Case no. } 6 \text { and } 17 \text {, codon } 158 \\
\text { TAC (Tyr) } \rightarrow \text { GCT (Stop codon) }\end{array}$ & $2 / 29$ \\
\hline $\begin{array}{l}\text { Astrocytoma } \\
\text { (low grade) }\end{array}$ & $\begin{array}{l}\text { Case no. 5, codon } 96 \\
\text { AGT (Ser) } \rightarrow \text { GCT (Gly) }\end{array}$ & $1 / 11$ \\
\hline $\begin{array}{l}\text { Astrocytoma } \\
\text { (high grade) }\end{array}$ & $\begin{array}{l}\text { Case no. 12, codon } 111 \\
\text { TCG (Ser) } \rightarrow \text { TTG (Leu) }\end{array}$ & $1 / 23$ \\
\hline Metastasis & $\begin{array}{l}\text { Case no. 4, codon } 111 \\
\text { TCG (Ser) } \rightarrow \text { TTG (Leu) } \\
\text { codon } 119 \\
\text { TCT }(\text { Ser }) \rightarrow \text { TAT }(\text { Tyr })\end{array}$ & $1 / 6$ \\
\hline
\end{tabular}

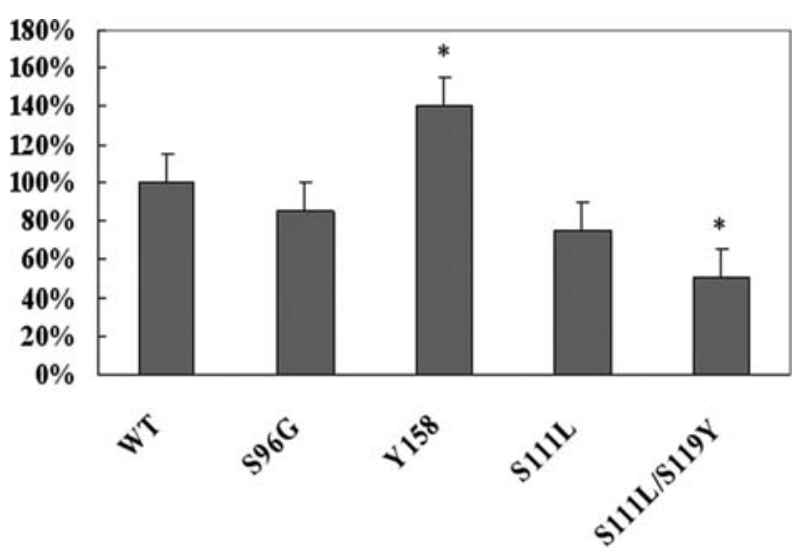

Figure 3. Effects of Snail mutants on the E-Cadherin promoter reporter assay. HEK293 cells were transfected with $2.0 \mu \mathrm{g}$ of pBabe, wild-type (WT), S96G, Y158*, S111L and S119Y Snail, together with $8 \mu \mathrm{g}$ of pGL2Basic-EcadK1 luciferase reporter. pSEAP-control $(1 \mu \mathrm{g})$ (Clontech) was co-transfected to normalize transfection efficiency. The percentage change of individual mutants indicates transcriptional activity compared to wild-type snail. Data are presented as mean $\pm \mathrm{SD}$. p-values were determined using a Student's t-test, ${ }^{*} \mathrm{p}<0.01$.

repressing capability of the premature truncated mutant was much less potent in suppressing the transcription of E-cadherin promoter compared to wild-type Snail. 


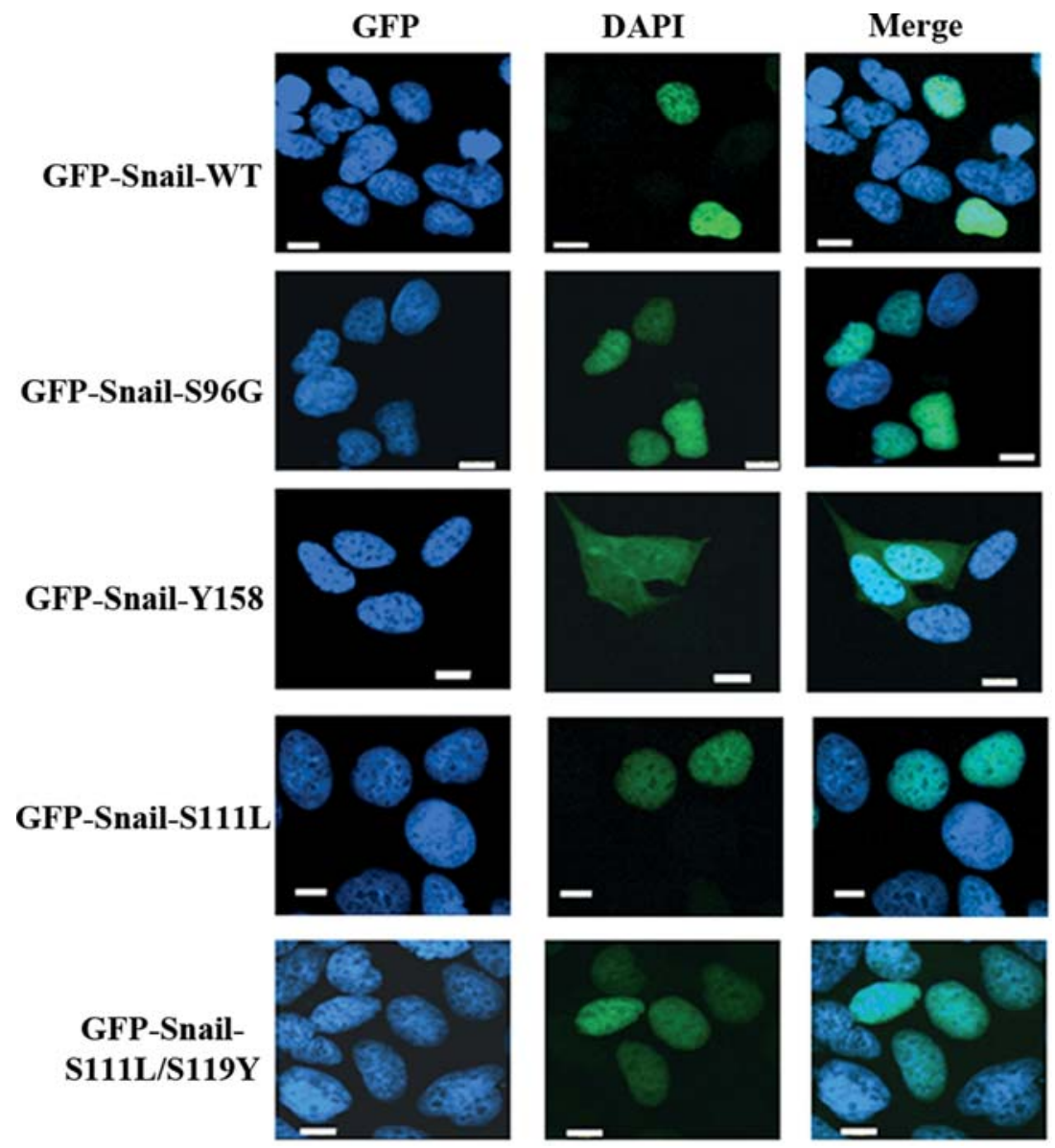

Figure 4. The localization of GFP-Snail mutant in HEK293 cells. S96G, S111L and S119Y Snail mutants translocated into the nucleus and the Y158* failed to translocate into the nucleus.

Table V. Summary of promoter activity and localization of Snail and its mutants.

\begin{tabular}{lcll}
\hline Snail & $\begin{array}{c}\text { Relative promoter } \\
\text { activity }(\%)\end{array}$ & Localization & \\
\hline WT & 100 & Nuclear & Pranscriptional repressor \\
S96G & 85 & Nuclear & $\begin{array}{l}\text { Effect on the GSK3ß phosphorylation motif I } \\
\text { Y158* }\end{array}$ \\
& 140 & Cytoplasm & $\begin{array}{l}\text { Effect on truncated first Zinc finger domain and lost its DNA } \\
\text { binding ability } \\
\text { S111L }\end{array}$ \\
& 75 & n.d. & $\begin{array}{l}\text { Effect on the GSK3ß phosphorylation motif II and Snail nuclear } \\
\text { export motif } \\
\text { S111L/S119Y }\end{array}$ \\
& 50 & Nuclear & $\begin{array}{l}\text { Effect on the GSK3ß phosphorylation motif II and Snail nuclear } \\
\text { export motif }\end{array}$ \\
\hline
\end{tabular}

n.d., not detected.

Subcellular localization of Snail mutants. Snail proteins have to translocate into the nucleus for its repressor function. We next checked whether these Snail mutations could affect the translocation of Snail into the nucleus in HEK293 cells. The data showed the localization of wild-type, S96G and S111L/ S119Y inside nucleus. In contrast, the Y158* truncated mutant failed to translocate into the nucleus (Fig. 4 and Table V).

\section{Discussion}

In the present study, Shh (22/69), Smo (35/69), Ptch (50/69), Gli1 (56/69), Gli2 (29/69) and N-myc (39/69) expression was found in brain tumor specimens (Table II). These data indicated that the overexpression of Ptch and Gli1 might contribute to brain tumorigenesis. Ptch acts as a classic tumor suppressor 
gene. Ptch mutations have also been found in many sporadic malignancies $(6,34-36)$. Ptch mutations may also exist in this study. It should be noted that Gli1 was expressed more often than Gli2 and appeared to be more important than Gli2 in brain tumors, but not in low grade astrocytoma (Fig. 1 and Table II). In addition, our data indicated that E-cadherin expression was lower in malignant tumors (high grade astrocytoma and metastasis, 39 and 50\%, respectively), and more highly expressed in benign tumors (meningioma, 96\% and low grade astrocytoma, 75\%) (Table III). These results indicated that E-cadherin is expressed at different levels in various brain tumors, and reinforce the idea that the loss of E-cadherin is a malignant characteristic. Several studies have previously shown similar results $(3,37-40)$. In addition, loss of E-cadherin during developmental EMT can switch ß-catenin from its role at adherents junctions to a role into nuclear transcription, which has been suggested to be important in the development of tumor invasion $(27,28)$. Our data showed that Snail acted as a repressor of E-cadherin promoter and regulated E-cadherin gene expression in astrocytoma (high grade) and metastatic tumors but not in meningioma (Table III). These findings are consistent with previous reports that Snail acted as a transcriptional repressor of E-cadherin and an inducer of EMT in tumor invasion $(27,28,41)$.

Both Gli and Snail are transcriptional factors and depend on GSK3ß for their stability and function. We therefore further investigated mutations on the GSK3ß regulation domain of Gli1 and Snail by RT-PCR and direct sequencing. The data showed no mutations were observed on Gli2 (data not shown), whereas several mutations on Snail S96G, S111L, S111L/S119Y and one nonsense mutation at codon 158 (Y158*) were found. The sequencing data show that of the four mutations revealed the S96G mutation affected GSK3ß speculative phosphorylation motif I and the S111L and S111L/S119Y mutations speculative phosphorylation motif II and the nuclear export motif (Table V). We conclude that Snail gene mutations are a sporadic and rare event in brain tumors. Moreover, the stability of Snail is dependent on its phosphorylation by PKA, CK 1 and GSK $3 ß$ and inter-action with $\beta$-Trcp (33). The first GSK3ß phosphorylation motif overlapping the $\beta$-Trcp destruction box, DSGXXS, which is also present in $\beta$-catenin and IкB $(33,42,43)$. Our data showed that the S96G mutant disrupted the first GSK3B phosphorylation motif overlaps with the B-Trcp destruction box, resulting in more stable mutant Snail. The S111L/S119Y double mutant altered the speculative phosphorylation motif II and nuclear export motif. Based on the promoter assay data, the transcriptional capability of S111L/S119Y decreased $50 \%$ compared to wild-type Snail, whereas the Y $158^{*}$ increased $40 \%$ compared to wild-type Snail. These findings may imply that the S111L/S119Y mutation is more important in metastasis brain tumors (Tables IV and V). We also checked whether the Snail mutations affected the translocation of Snail into the nucleus. Our data indicated that wild-type, S96G and S111L/S119Y translocated into the nucleus, but the Y158* truncated mutant failed to translocate into the nucleus (Fig. 4). These findings are consistent with previous reports that the phosphorylation motifs and zinc finger of Snail affect its transcriptional activity $(33,44)$. We summarized the promoter activity and localization of Snail and its mutants in Table V.
In conclusion, our results demonstrate that expression of the Hh pathway (particularly for Gli1), expression and mutations of Snail, and expression of E-cadherin may play a role in human brain tumorigenesis. Together with our previous reports on the Wnt pathway (3-5), the data seem to imply that the interplay of Wnt, and Gli in the Hh pathway and Snail/E-cadherin be important factors in brain tumorigenesis and potentially may be worthwhile targets for molecular diagnosis or cancer therapy.

\section{Acknowledgements}

This study was supported by NSC 97-2314-0B-037-013, NSC 98-2314-B-037-001 (Taiwan) and Chi-Mei 94CM-KMU-11 to SLH; NSC96-2320-B-037-004 (Taiwan) to Y.-R.H.

\section{References}

1. Lunsford LD, Somaza S, Kondziolka D and Flickinger JC: Survival after stereotactic biopsy and irradiation of cerebral non-anaplastic, non-pilocytic astrocytoma. J Neurosurg 82: 523-529, 1995.

2. Kleihues P, Burger PC and Scheithauer BW: The new WHO classification of brain tumours. Brain Pathol 3: 255-268, 2000.

3. Howng SL, Wu CH, Cheng TS, Sy WD, Lin PC, Wang C and Hong YR: Differential expression of Wnt genes, beta-catenin and E-cadherin in human brain tumors. Cancer Lett 83: 95-101, 2002.

4. Howng SL, Huang FH, Hwang SL, Lieu AS, Sy WD, Wang C and Hong YR: Differential expression and splicing isoform analysis of human Tcf-4 transcription factor inbrain tumors. Int J Oncol 25: 1685-1692, 2004.

5. Lee CI, Hsu MY, Chou CH, Wang C, Lo YS, Loh JK, Howng SL and Hong YR: CTNNB1 (beta-catenin) mutation is rare in brain tumours but involved as a sporadic eventin a brain metastasis. Acta Neurochir (Wien) 151: 1107-1111, 2009.

6. Lindström E, Shimokawa T, Toftgård R and Zaphiropoulos PG: PTCH mutations: distribution and analyses. Hum Mutat 27: 215-219, 2006.

7. Pasca DI, Magliano M and Hebrok M: Hedgehog signaling in cancer formation and maintenance. Nat Rev Cancer 3: 903-911, 2003.

8. Kasper M, Regl G, Frischauf AM and Aberger F: GLI transcription factors: mediators of oncogenic Hedgehog signalling. Eur J Cancer 42: 437-445, 2006.

9. Berman DM, Karhadkar SS, Hallahan AR, Pritchard JI, Eberhart CG, Watkins DN, Chen JK, Cooper MK, Taipale J, Olson JM and Beachy PA: Medulloblastoma growth inhibition by hedgehog pathway blockade. Science 297: 1559-1561, 2002.

10. Romer JT, Kimura H, Magdaleno S, Sasai K, Fuller C, Baines H, Connelly M, Stewart CF, Gould S, Rubin LL and Curran T: Suppression of the Shh pathway using a small molecule inhibitor eliminates medulloblastoma in Ptc1(+/-)p53(-/-)mice. Cancer Cell 6: 229-240, 2004.

11. Lum L and Beachy PA: The Hedgehog response network: sensors, switches and routers. Science 18: 1755-1759, 2004.

12. Zhu AJ, Zheng L, Suyama K and Scott MP: Altered localization of Drosophila Smoothened protein activates Hedgehog signal transduction. Genes Dev 17: 1240-1252, 2003.

13. Price MA and Kalderon D: Proteolysis of the Hedgehog signaling effector Cubitus interruptus requires phosphorylation by Glycogen Synthase Kinase 3 and Casein Kinase 1. Cell 108: 823-835, 2002.

14. Jia J, Amanai K, Wang G, Tang J, Wang B and Jiang J: Shaggy/ GSK3 antagonizes Hedgehog signalling by regulating Cubitus interruptus. Nature 416: 548-552, 2002.

15. Ruiz i Altaba A, Mas C and Stecca B: The Gli code: an information nexus regulating cell fate, stemness and cancer. Trends Cell Biol 17: 438-447, 2007.

16. Epstein DJ, Marti E, Scott MP and McMahon AP: Antagonizing cAMP-dependent protein kinase A in the dorsal CNS activates a conserved Sonic hedgehog signaling pathway. Development 122: 2885-2894, 1996. 
17. Wang B, Fallon JF and Beachy PA: Hedgehog-regulated processing of Gli3 produces an anterior/posterior repressor gradient in the developing vertebrate limb. Cell 100: 423-434, 2000.

18. Hatton BA, Knoepfler PS, Kenney AM, Rowitch DH, De Alboran IM, Olson JM and Eisenman RN: N-myc is an essential downstream effector of Shh signaling during both normal and neoplastic cerebellar growth. Cancer Res 66: 8655-8661, 2006.

19. Kalderon D: Similarities between the Hedgehog and Wnt signaling pathways. Trends Cell Biol 11: 523-531, 2002.

20. Li X, Deng W, Lobo-Ruppert SM and Ruppert JM: Gli1 acts through Snail and E-cadherin to promote nuclear signaling by beta-catenin. Oncogene 26: 4489-4498, 2007.

21. Yook JI, Li XY, Ota I, Fearon ER and Weiss SJ: Wnt-dependent regulation of the E-cadherin repressor snail. J Biol Chem 280: 11740-11748, 2005.

22. Cavallaro U and Christofori G: Cell adhesion and signalling by cadherins and Ig-CAMs in cancer. Nat Rev Cancer 4: 118-132, 2004.

23. Nelson WJ and Nusse R: Convergence of Wnt, betacatenin and cadherin pathways. Science 303: 1483-1487, 2004.

24. Gumbiner BM: Regulation of cadherin-mediated adhesion in morphogenesis. Nat Rev Mol Cell Biol 6: 622-634, 2005.

25. Brembeck FH, Rosario M and Birchmeier W: Balancing cell adhesion and Wnt signaling, the key role of beta-catenin. Curr Opin Genet Dev 16: 51-59, 2006.

26. Becker KF, Rosivatz E, Blechschmidt K, Kremmer E, Sarbia M and Hofler H: Analysis of the E-cadherin repressor Snail in primary human cancers. Cells Tissues Organs 185: 204-212, 2007.

27. Batlle E, Sancho E, Franci C, Dominguez D, Monfar M, Baulida $\mathbf{J}$ and Garcia DH: The transcription factor Snail is a repressor of E-cadherin gene expression in epithelial tumour cells. Nat Cell Biol 2: 84-89, 2000.

28. Cano A, Perez-Moreno MA, Rodrigo I, Locascio A, Blanco MJ, Del Barrio MG, Portillo F and Nieto MA: The transcription factor Snail controls epithelial-mesenchymal transitions by repressing E-cadherin expression. Nat Cell Biol 2: 76-83, 2000.

29. Nieto MA: The snail superfamily of zinc-finger transcription factors. Nat Rev Mol Cell Biol 3: 155-166, 2002.

30. Barbera MJ, Puig I, Dominguez D, Julien-Grille S, GuaitaEsteruelas S, Peiro S, Baulida J, Franci C, Dedhar S, Larue L and Garcia de Herreros A: Regulation of Snail transcription during epithelial to mesenchymal transition of tumor cells. Oncogene 23: 7345-7354, 2004.

31. De Craene B, van Roy F and Berx G: Unraveling signalling cascades for the Snail family of transcription factors. Cell Signal 17: 535-547, 2005.
32. Yook JI, Li XY, Ota I, Hu C, Kim HS, Kim NH, Cha SY, Ryu JK, Choi YJ, Kim J, Fearon ER and Weiss SJ: A Wnt-Axin2GSK3beta cascade regulates Snaill activity in breast cancer cells. Nat Cell Biol 8: 1398-1406, 2006.

33. Zhou BP, Deng J, Xia W, Xu J, Li YM, Gunduz M and Hung MC: Dual regulation of Snail by GSK-3beta-mediated phosphorylation in control of epithelial-mesenchymal transition. Nat Cell Biol 6: 931-940, 2004.

34. Gailani MR, Ståhle-Bäckdahl M, Leffell DJ, Glynn M, Zaphiropoulos PG, Pressman C, Undén AB, Dean M, Brash DE, Bale AE and Toftgård R: The role of the human homologue of Drosophila patched in sporadic basal cell carcinomas. Nat Genet 14: 78-81, 1996.

35. Barreto DC, Gomez RS, Bale AE, Boson WL and De Marco L: PTCH gene mutations in odontogenic keratocysts. J Dent Res 79: 1418-1422, 2000.

36. Toftgård R: Hedgehog signalling in cancer. Cell Mol Life Sci 57: $1720-1731,2000$

37. Asano K, Kubo O, Tajika Y, Takakura K and Suzuki S: Expression of cadherin and CSF dissemination in malignant astrocytic tumors. Neurosurg Rev 23: 39-44, 2000.

38. Utsuki S, Sato Y, Oka H, Tsuchiya B, Suzuki S and Fujii K: Relationship between the expression of E-, N-cadherins and beta-catenin and tumor grade in astrocytomas. J Neurooncol 57: 187-192, 2002

39. Utsuki S, Oka H, Sato Y, Tsutiya B, Kondo K, Tanizaki Y, Tanaka $S$ and Fujii KE: N-cadherins and beta-catenin expression in medulloblastoma and atypical teratoid/rhabdoid tumor. Neurol Med Chir (Tokyo) 44: 402-406, 2004.

40. Motta FJ, Valera ET, Lucio-Eterovic AK, Queiroz RG, Neder L, Scrideli CA, Machado HR, Carlotti-Junior CG, Marie SK and Tone LG: Differential expression of E-cadherin gene in human neuroepithelial tumors. Genet Mol Res 7: 295-304, 2008.

41. Barrallo-Gimeno A and Nieto MA: The Snail genes as inducers of cell movement and survival: implications in development and cancer. Development 132: 3151-3161, 2005.

42. Fodde R, Smits R and Clevers H: APC, signal transduction and genetic instability in colorectal cancer. Nat Rev Cancer 1: 55-67, 2001.

43. Guardavaccaro D, Kudo Y, Boulaire J, Barchi M, Busino L, Donzelli M, Margottin-Goguet F, Jackson PK, Yamasaki L and Pagano M: Control of meiotic and mitotic progression by the $\mathrm{F}$ box protein beta-Trcp1 in vivo. Dev Cell 4: 799-812, 2003.

44. Mingot JM, Vega S, Maestro B, Sanz JM and Nieto MA: Characterization of Snail nuclear import pathways as representatives of $\mathrm{C} 2 \mathrm{H} 2$ zinc finger transcription factors. J Cell Sci 122: 1452-1460, 2009. 